\title{
PENINGKATAN KETRAMPILAN KELOMPOK WANITA DESA PASIE PINANG MELALUI PELATIHAN PRODUK OLAHAN IKAN PATIN
}

\section{IMPROVING THE SKILLS OF WOMEN PASIE PINANG VILLAGES THROUGH PATIN PROCESSED PRODUCTS TRAINING}

\author{
Nabila Ukhty ${ }^{1}$, Yasrizal ${ }^{2}$ \\ ${ }^{1}$ Program Studi Perikanan, Fakultas Perikanan dan IImu Kelautan, Universitas Teuku Umar \\ ${ }^{2}$ Program Studi Ekonomi Pembangunan, Fakultas Ekonomi, Universitas Teuku Umar \\ *Korespondensi: nabilaukhty@utu.ac.id
}

\begin{abstract}
ABSTRAK
Ikan patin merupakan ikan air tawar yang banyak dibudidayakan oleh petani ikan di Desa Pasie Pinang. Pemanfaatan ikan tersebut belum optimal. Oleh karena itu tujuan kegiatan pengadian kepada masyarakat ini yaitu untuk mengoptimalkan pemanfaatan ikan patin melalui pelatihan produk olahan ikan patin menjadi makanan sehat. Kegiatan pelatihan terdiri dari tiga tahapan, yaitu persiapan, pelaksanaan dan evaluasi. Pada tahapan pelaksanaan, materi yang diberikan kepada peserta terdiri dari cara penanganan ikan, jenis produk olahan ikan patin, pengemasan dan labeling, dan penetapan harga jual. Kelompok wanita Desa Pasie Pinang sangat antusias mengikuti kegiatan pelatihan. Capaian yang diperoleh dari kegiatan ini diantaranya peserta dapat mengembangkan ikan patin menjadi produk dengan nilai jual yang tinggi, dapat melakukan proses pengolahan produk ikan patin berbasis skala rumah tangga, dapat memproduksi olahan ikan patin secara mandiri, dan dapat melakukan kegiatan pemasaran produk olahan ikan patin.
\end{abstract}

Kata kunci: Ikan patin, pasie pinang, produk.

\section{ABSTRACT}

Catfish is a freshwater fish that is widely cultivated by fish farmers in Pasie Pinang Village. Utilization of fish is not yet optimal. Therefore, the purpose of this community service is to optimize the use of catfish through training in processed catfish products into healthy food. The training activities consist of three stages, namely preparation, implementation and evaluation. At the implementation stage, the material provided to participants consisted of ways of handling fish, types of processed catfish products, packaging and labeling, and determining the selling price. Pasie Pinang Village women's group was very enthusiastic in participating in the training activities. The achievements obtained from this activity include participants being able to develop catfish into products with high selling value, being able to process catfish products based on a household scale, being able to produce processed catfish independently, and being able to conduct marketing activities of processed catfish products.

Keywords: Catfish, Pinang Pasie, Products.

\section{PENDAHULUAN}

Pasie Pinang merupakan salah satu Desa yang ada di Kabupaten Aceh Barat, dengan luas wilayah sebesar $1,57 \mathrm{Km}^{2}$. Secara geografis Desa Pasie Pinang terletak di sepanjang Sungai Pasi Pinang (Anonim 2019). Letak geografis inilah yang berpotensi terhadap hasil perikanan di Desa Pasie Pinang, salah satunya yaitu Ikan Patin.

Ikan patin (Pangasius sp.) merupakan jenis ikan patin asli Indonesia yang banyak tersebar di Sumatera, Kalimantan dan sebagian Jawa (Thuy et al, 2002). Ikan patin juga diketahui memiliki kandungan gizi yang sangat baik. Hal ini seperti yang 
telah diinfomasikan oleh Ariyanto dan Utami (2006); Domiszewski et al. (2011); Orban et al. (2008) yaitu secara secara umum ikan patin memiliki kandungan protein 13,13$68,60 \%$, lemak 1,09-5,80\%, karbohidrat $1,50 \%$, abu 0,17-5,0\% dan air 59,3-75,5\%. Secara aspek ekonomi, ikan patin menjadi ikan konsumsi utama oleh penduduk Desa Pasie Pinang. Kegiatan budidaya ikan patin terus dilakukan untuk peningkatan ekonomi rumah tangga.

Tingginya produksi ikan patin dari hasil tangkapan sungai maupun hasil budidaya belum sejalan dengan pemanfaatannya. Ikan patin hanya dikonsumsi secara local oleh penduduk Desa Pasie Pinang. Keterbatasan sarana prasarana memperkecil jangkauan pemasaran ikan patin. Selain itu, minimnya ketrampilan menyebabkan para pembudidaya ikan di Desa tersebut hanya berfokus pada pengembangan budidaya ikan saja sedangkan pada pengembangan produk olahan ikan patin untuk meningkatkan nilai tambah ini belum pernah terpikirkan sebelumnya.

Oleh karena itu, berdasarkan analisis situasi di Desa Pasie Pinang ini maka warga perlu dilalukan kegiatan pelatihan pengolahan ikan patin sehingga bisa mengolah ikan secara variatif dan produktif. Sesuai dengan analisis situasi dan latar belakang di atas, maka tujuan dari pelatihan ini yaitu, melatih kelompok wanita Pasie Pinang untuk mengolah ikan patin menjadi makanan variatif dan produktif.

\section{METODE KEGIATAN}

Kegiatan pelaksaanan program Pengabdian Masyarakat dilakukan di Desa Pasie Pinang, Kecamatan Meureubo, Aceh Barat. Kegiatan ini terdiri dari dua tahapan, yaitu tahap pertama menjalin dan membentuk kemitraan dan tahapan yang kedua yaitu memberikan pelatihan pembuatan produk-produk olahan hasil perikanan berbahan dasar ikan patin. Adapun produk yang diperkenalkan ke masyarakat yaitu, stick dan bakso ikan patin. Lokasi kegiatan dapat dilihat pada Gambar 1.

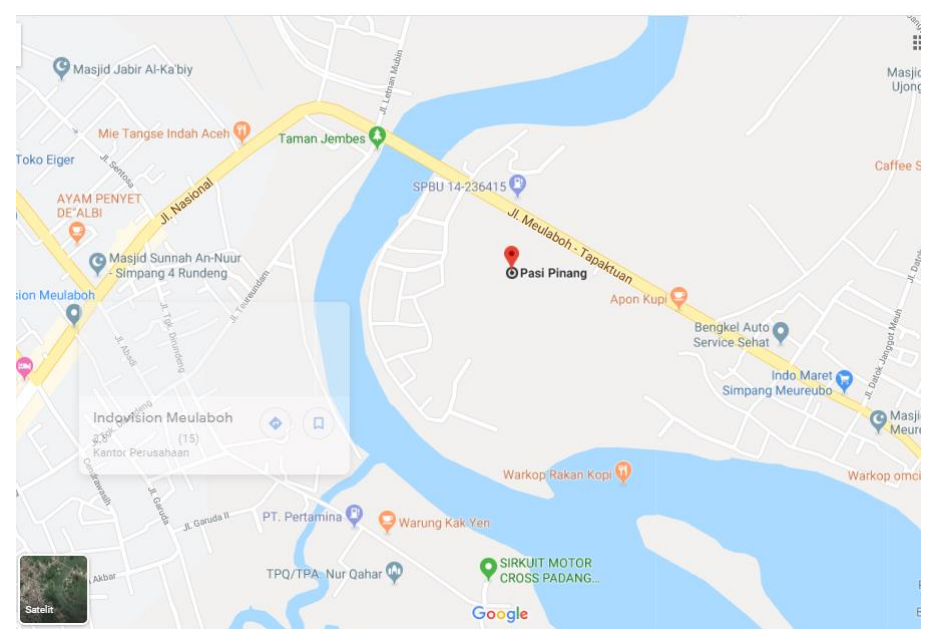

Gambar 1. Lokasi Desa Pasie Pinang (Sumber : Google Map)

\section{Metode Penerapan Ipteks}

Kegiatan pelatihan pengolahan perikanan yang dilakukan menggunakan pendekatan pembelajaran orang dewasa. Metode yang digunakan adalah ceramah, 
tanya jawab dan praktek langsung pengolahan hasil perikanan. Kegiatan pelatihan ini dilakukan dengan melalui beberapa langkah meliputi:

a. Persiapan

Koordinasi dengan mitra, penentuan waktu pelaksanaan, menjalin kerjasama dengan mitra, persiapan alat dan bahan yang dibutuhkan untuk pelatihan, publikasi/undangan dan administrasi.

b. Pelaksanaan

Pelaksanaan kegiatan pengabdian dilakukan dengan melibatkan tenaga ahli dan mitra. Adapun pelatihan yang diberikan kepada mitra ameliputi pengolahan produk, manajemen dan kewirausahaan produk. Selanjutnya mitra diberikan pula pelatihan yang terkait dengan manajemen usaha yaitu pengemasan produk, penentuan harga jual produk, penyusunan laporan keuangan/ pembukuan sederhana dan penyusunan rencana bisnis.

c. Evaluasi dan tindak lanjut

Evaluasi terhadap peningkatan kemampuan mitra sebelum dan sesudah pelatihan.

\section{HASIL DAN PEMBAHASAN}

Pemberian materi teknologi pengolahan ikan patin meliputi penanganan bahan, sanitasi higiene, pengemasan, pelabelan, penentuan harga jual dan strategi pemasaran produk. Peserta pelatihan mendapatkan hand-out materi yang akan diberikan. Materi penanganan bahan diperlukan agar peserta mengerti pentingnya penanganan bahan baku terhadap kualitas produk yang dihasilkan.

\section{A. Penanganan}

Ikan memerlukan penanganan yang cepat karena sifat ikan yang mudah membusuk dikarenakan tingginya kadar protein di dalam daging ikan. Penanganan produk meliputi pembersihan, pemilihan, penyimpanan. Sanitasi higiene meliputi higiene personal, pakaian, lingkungan kerja, dan peralatan. Kebersihan ketika penanganan bahan baku, pengolahan hingga pengemasan sangat penting diperhatikan untuk memberikan produk yang aman dan bersih. Adapun penerapan sanitasi dan higien peserta pelatihan dapat dilihat pada Gambar 2.

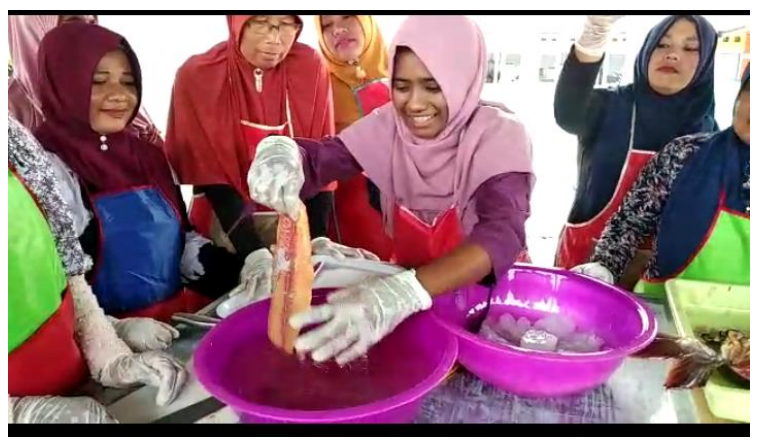

Gambar 2. Penerapan Sanitasi Pada Kegiatan Pengolahan Produk

Pada Gambar 2 dapat dilihat, peserta pelatihan diwajibkan untuk menggunakan sarung tangan dan apron agar dapat mengurangi terjadinya kontaminasi mikroba pada saat proses pengolahan. Selain itu, pada kegiatan ini juga 
diberikan pengetahuan bagaimana cara penangana ikan sebelum diolah, yaitu pemilihan ikan yang masih segar dan pemberian es pada setiap wadah. Hal ini bertujuan untuk melindungi daging ikan dari kerusakan yang diakibatkan oleh mikroba.

B. Produk Olahan ikan patin

Pada kegiatan ini, diberikan pengetahuan mengenai produk olahan ikan patin, yaitu bakso ikan patin dan stick ikan patin. Adapun kegiatan pengolahan ikan patin dapat dilihat pada Gambar 3, 4, 5, 6 dan 7.

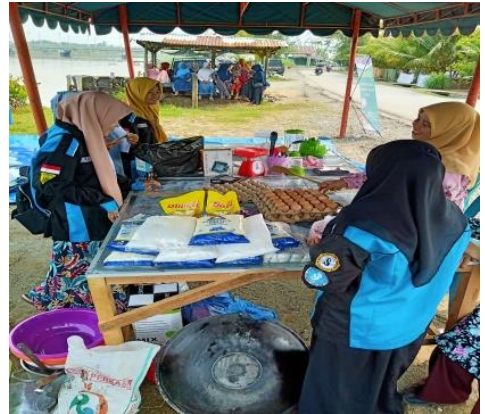

Gambar 3. Persiapan Bahan dan Alat

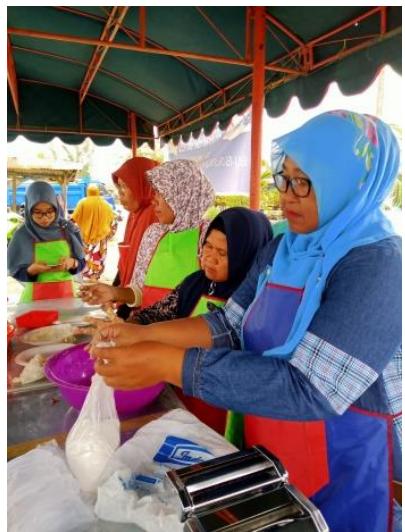

Gambar 5. Pencampuran adonan

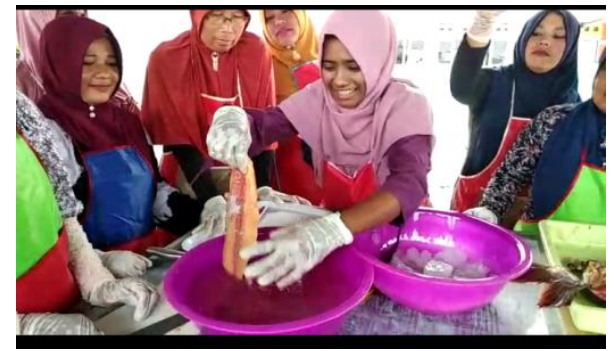

Gambar 4. Preparasi Bahan Baku (Fillet

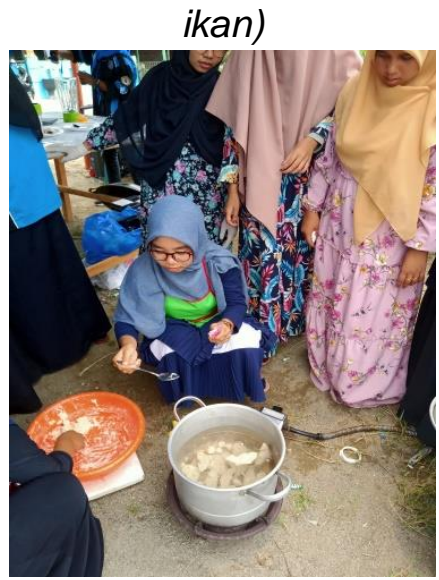

Gambar 6. Perebusan Bakso

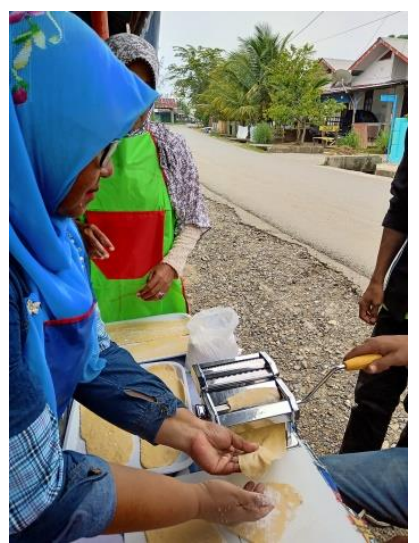

Gambar 7. Pencetakan stick ikan patin 
C. Pengemasan dan labeling

Pemilihan jenis kemasan, peralatan pengemasan yang sesuai dengan jenis kemasan yang digunakan. Peserta diberikan informasi mengenai bagaimana memilih jenis kemasan yang disesuaikan dengan produk yang akan dikemas. Sedangkan informasi terkait labeling diberikan kepada peserta agar mengetahui pesyaratan informasi apa yang harus ada dalam label pangan sesuai dengan undang-undang label pangan. Kemasan prok olahan ikan patin dapat dilihat pada Gambar 8.

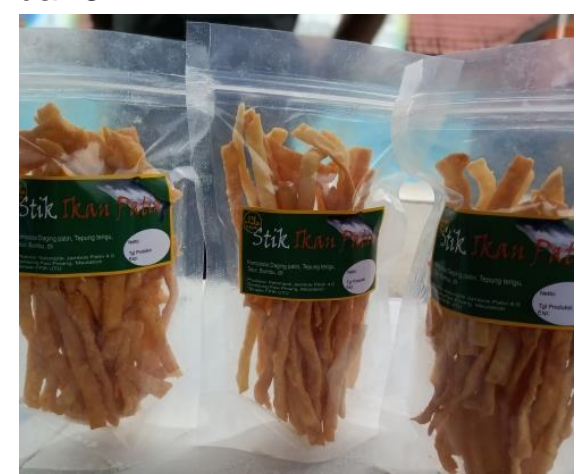

Gambar 8. Kemasan dan label produk stick ikan patin

D. Penetapan harga jual

Materi ini didasarkan pada produk yang dibuat oleh peserta. Hal ini dimaksudkan agar peserta memiliki gambaran bagaiamana menentukan harga jual suatu produk dan dapat diaplikasikan pada pembuatan produk yang lain.

E. Pemasaran

Teori dan aplikasi praktis mengenai strategi pemasaran dan bagaimana merebut pasar diberikan sebagai upaya untuk memberikan gambaran dan memilih cara pemasaran yang paling tepat untuk produk olahan ikan patin.

Adapun target atau capaian yang diperoleh dari kegiatan ini diantaranya :

1. Jumlah kehadiran peserta minimal $80 \%$ dari peserta yang diundang

2. Peserta dapat mengembangkan komoditi local, khususnya ikan patin menjadi produk dengan nilai jual yang tinggi;

3. Peserta dapat melakukan proses pengolahan produk ikan patin berbasis skala rumah tangga;

4. Perserta dapat memproduksi olahan ikan patin secara mandiri;

5. Peserta dapat melakukan kegiatan pemasarab produk olahan ikan patin, baik secara langsung ataupun secara online

Pelatihan pengolahan produk ikan patin ini meningkatkan ketrampilan masyarakat, khususnya ibu rumah tangga di Desa Pasie Pinang. Ketrampilan yang dimiliki oleh ibu-ibu rumah tangga diharapkan dapat meningkatkan pendapatan masyarakat di Desa Pasie Pinang, Aceh Barat, sehingga dapat membantu kesejahteraan dan kemakmuran keluarga. Dengan meningkatnya perekonomian keluarga, maka akan meningkatkan taraf pendidikan masyarakat, khususnya untuk generasi-generasi penerus. 
Ikan merupakan bahan pangan yang mengandung protein hewani yang sangat dibutuhkan oleh tubuh, khususnya untuk anak-anak bayi dan balita. Sehingga dapat mengurangi resiko stunting pada anak. Stunting pada balita perlu menjadi perhatian khusus karena dapat menghambat perkembangan fisik dan mental anak (Purwandini dan Kartasurya 2013). Stunting berkaitan dengan peningkatan risiko kesakitan dan kematian serta terhambatnya pertumbuhan kemampuan motorik dan mental. Balita yang mengalami stunting memiliki risiko terjadinya penurunan kemampuan intelektual, produktivitas, dan peningkatan risiko penyakit degeneratif di masa mendatang (WHO 2012; UNICEF 2013 dalam Rachim dan Pratiwi 2017). Sehingga kegiatan penganekaragaman produk olahan berbahan dasar ikan ini menjadi alternatif untuk menyediakan makanan cemilan sehat untuk anak-anak.

\section{KESIMPULAN}

Ikan patin sebagai salah satu ikan air sungai yang memiliki potensi untuk diolah menjadi produk olahan yang bervariatif. Produk olahan yang ada merupakan pemanfaatan dari daging menjadi beberapa produk, diantaranya bakso ikan dan stick ikan. Proses diversifikasi pengolahan ikan ini membutuhkan teknologi untuk dapat meningkatkan outputnya, sehingga perlu peningkatan sarana prasarana pada unit usaha ibu rumah tangga.

\section{DAFTAR PUSTAKA}

Anonim. 2019. Letak geografis Desa Pasie Pinang, Aceh Barat. https://id.wikipedia.org/wiki/Pasi_Pinang,_Meureubo,_Aceh_Barat _ . [30 September 2019].

Ariyanto D, Utami, R. 2006. Evaluasi laju pertumbuhan, keragaman genetik dan estimasi heterosis pada persilangan antar spesies ikan patin (Pangasius sp.). Jurnal Perikanan. VIII (1): 81-86.

Domiszewski Z, Bienkiewicz G, Plust D. 2011. Effects of different heat treatments on lipid quality of striped catfish (Pangasius hypophthalmus). Acta Scientiarum Polonorum, Technol. Aliment. 10(3): 359-373.

Orban E, Nevigato T, Lena GD, Masci M, Casini I, Gambelli L, Caproni, R. 2008. New trend in the seafood market sutchi catfish (Pangasius hypopthalmus) filet from Vietnam: nutritional quality and safety aspect. Journal of Food Chemistry. 110(2):383-389.

Purwandini K, Kartasurya M. 2013. Pengaruh pemberian mikronutrient sprinkle terhadap perkembangan motorik anak stunting usia 12-36 bulan. Journal of Nutrition College. 2(1): p.147-163.

Rachim ANF, Pratiwi R. 2017. Hubungan konsumsi ikan terhadap kejadian stunting pada anak usia 2-5 tahun. Jurnal Kedokteran Diponegoro. 6(1): 36-45.

Thuy NT, Loc NT, Linberg JE, Ogle B. 2002. Survey of the production, processing and nutritive value of catfish by-product meals in the Mekong Delta of Vietnam. Journal of Louisiana Agriculture. 